\title{
Biologically Inactive Growth Hormone Caused by an Amino Acid Substitution
}

\author{
Yutaka Takahashi, ${ }^{*}$ Hiroyuki Shirono, ${ }^{\ddagger}$ Osamu Arisaka,§ Kenichi Takahashi, ${ }^{\ddagger}$ Toshihiro Yagi,‡ Junichi Koga,‡ Hidesuke Kaji, ${ }^{\star}$ \\ Yasuhiko Okimura, ${ }^{*}$ Hiromi Abe, ${ }^{*}$ Toshiaki Tanaka," and Kazuo Chihara* \\ *Third Division, Department of Medicine, Kobe University School of Medicine, Kobe, 650, Japan; ${ }^{\ddagger}$ Laboratories for Bioengineering and \\ Research, Japan Chemical Research Pharmaceuticals Co., Ltd., Kobe, 651-22, Japan; ${ }^{\S}$ Department of Pediatrics, Juntendo University \\ School of Medicine, Tokyo, 113, Japan; and ${ }^{\|}$Department of Endocrinology, National Children's Hospital, Tokyo, 154, Japan
}

\begin{abstract}
Short stature caused by biologically inactive growth hormone (GH) is characterized by lack of GH action despite high immunoassayable GH levels in serum and marked catch-up growth to exogenous GH administration. We found a heterozygous single-base substitution $(A \rightarrow G)$ in exon 4 of the GH-1 gene of a girl with short stature, clinically suspected to indicate the presence of bioinactive $\mathrm{GH}$ and resulting in the substitution of glycine for aspartic acid at codon 112. We confirmed the presence of mutant GH in the serum using isoelectric focusing analysis. The locus of mutation D112G was found within site 2 of the GH molecule in binding with $\mathrm{GH}$ receptor (GHR)/GH binding protein (GHBP). The expressed recombinant mutant $\mathrm{GH}$ tended to form a 1:1 instead of the 1:2 GH-GHBP complex normally produced by wild-type GH. The formation of a 1:2 GH-GHBP complex is compatible with the dimerization of GHRs by GH, a crucial step in GH signal transduction. Mutant GH was less potent than wild-type GH not only in phosphorylation of tyrosine residues in GHR, janus kinase 2 (JAK2), and signal transducers and activators of transcription 5 (STAT5) in IM-9 cells, but also in metabolic responses of $\mathrm{BaF} / \mathrm{GM}$ cells, a stable clone transfected with cDNA of the chimera of the extracellular domain of human GHR, the transmembrane and the cytoplasmic domain of the human thrombopoietin receptor. These results indicate that the D112G mutation in the GH-1 gene causes production of bioinactive $\mathrm{GH}$, which prevents dimerization of GHR and is therefore responsible for the patient's short stature. (J. Clin. Invest. 1997. 100:1159-1165.) Key words: short stature • bioinactive growth hormone $\bullet$ growth hormone gene $\bullet$ mutation $\bullet$ site 2
\end{abstract}

\section{Introduction}

Growth hormone $(\mathrm{GH})^{1}$ is essential for postnatal growth. The primary pituitary diseases and pituitary $\mathrm{GH}$ deficiency due to

Address correspondence to Dr. Yutaka Takahashi, Third Division, Department of Medicine, Kobe University School of Medicine, 7-5-1 Kusunoki-cho, Chuo-ku, Kobe, 650, Japan. Phone: 81-78-341-7451; FAX: 81-78-371-6468; E-mail: takahash@med.kobe-u.AC.jp

Received for publication 14 March 1997 and accepted in revised form 17 June 1997.

1. Abbreviations used in this paper: GH, growth hormone; GHBP, growth hormone binding protein; GRH, growth hormone receptor; JAK, janus kinase; rh, recombinant human; STAT, signal transducers and activators of transcription.

J. Clin. Invest.

(C) The American Society for Clinical Investigation, Inc. 0021-9738/97/09/1159/07 \$2.00

Volume 100, Number 5, September 1997, 1159-1165

http://www.jci.org hypothalamic dysfunction are the commonly held causes of $\mathrm{GH}$-dependent short stature. A rare type of GH-dependent short stature is due to $\mathrm{GH}$ insensitivity, where the GH signal fails to transduce normally in the cells. The prototypical syndrome of GH insensitivity is Laron-type dwarfism, in which the $\mathrm{GH}$ receptor (GHR) is deficient or defective. Insensitivity to intrinsic GH despite the presence of normal GHR could be caused by bioinactive $\mathrm{GH}$. Kowarski et al. first reported bioinactive GH in two children (1). Findings suggestive of circulating bioinactive $\mathrm{GH}$ include high immunoassayable $\mathrm{GH}$ levels (whether basal or stimulated), low basal IGF-1 levels, and marked IGF-1 increase after exogenous GH administration, followed by improved somatic linear growth. The incidence of short stature caused by bioinactive GH may be low (2), but several reports suggest the presence of Kowarski's syndrome (3-7). Valenta et al. reported a short child with circulating abnormal GH polymers (8) whose molecular basis is still unknown. We reported previously a short child with a mutant $\mathrm{GH}$ acting as a $\mathrm{GH}$ antagonist (9). We demonstrate here a case of short stature with a missense mutation in the GH-1 gene causing a reduction in $\mathrm{GH}$ action.

\section{Methods}

Case report. The proband was born at $41 \mathrm{wk}$ with a weight of $3,330 \mathrm{~g}$ and a height of $51 \mathrm{~cm}$. At the age of $3 \mathrm{yr}$, her height was $79.4 \mathrm{~cm}(3.6$ SD below the mean for age and sex). Her father's height was 161.0 $\mathrm{cm}$, and her mother's was $147.0 \mathrm{~cm}$. The parents were not related. Her sisters were all normal in height. Her bone age was delayed by $1.5 \mathrm{yr}$. On physical examination, she showed prominent forehead and hypoplastic nasal bridge with normal body proportions. Her serum IGF-1 level was $0.22 \mathrm{U} / \mathrm{ml}$ (normal range $0.30-1.50 \mathrm{U} / \mathrm{ml}$ ). Plasma GH levels increased from 11.0 to $26.0 \mathrm{ng} / \mathrm{ml}$ under insulin hypoglyce$\mathrm{mia}(0.1 \mathrm{U} / \mathrm{kg}$ regular insulin, intravenous injection), from 19.0 to 41.0 $\mathrm{ng} / \mathrm{ml}$ with glucagon propranolol $(0.03 \mathrm{mg} / \mathrm{kg}$ glucagon, intravenous injection, and $0.2 \mathrm{mg} / \mathrm{kg}$ propranolol, peroral ingestion), and from 3.7 to $51.0 \mathrm{ng} / \mathrm{ml}$ with $\mathrm{GH}$-releasing hormone $(1 \mu \mathrm{g} / \mathrm{kg}$, intravenous injection). Serum IGF-1 concentration was $0.28 \mathrm{U} / \mathrm{ml}$ at the basal level and increased to $1.21 \mathrm{U} / \mathrm{ml}$ after daily subcutaneous injections of 0.1 $\mathrm{U} / \mathrm{kg}$ recombinant human $\mathrm{GH}(\mathrm{rhGH})(0.035 \mathrm{mg} / \mathrm{kg})$ for $3 \mathrm{~d}$. After $1 \mathrm{yr}$ of treatment with $0.5 \mathrm{U} / \mathrm{kg} / \mathrm{wk}(0.18 \mathrm{mg} / \mathrm{kg} / \mathrm{wk})$ subcutaneous injection of rhGH, serum IGF-1 level was elevated to $3.20 \mathrm{U} / \mathrm{ml}$, and linear growth rate was improved, to $11.0 \mathrm{~cm} / \mathrm{yr}$ compared to $4.5 \mathrm{~cm} / \mathrm{yr}$ before treatment (Fig. 1). Serum GH-binding protein (GHBP) level was $9.33 \mathrm{ng} / \mathrm{ml}$ (normal range $3.20-73.89 \mathrm{ng} / \mathrm{ml}$ ).

Hormone assay. Serum human $\mathrm{GH}(\mathrm{hGH})$ concentrations were measured using an immunoradiometric assay kit (Pharmacia Biotech Inc., Piscataway, NJ).

GHBP assay. Serum GHBP concentrations were measured by a ligand-mediated immmunofunctional assay (10).

Isoelectric focusing analysis. Isoelectric focusing was performed as described previously (11), with modifications. Serum samples (200-300 $\mu \mathrm{l}$ ) were electrofocused in 1\% hydroxypropylmethylcellulose $/ 4 \%$ ampholine buffer (gradient $\mathrm{pH} 3.5-8.0$ ) at $200 \mathrm{~V}$ for $12 \mathrm{~h}$ and then at $500 \mathrm{~V}$ for $12 \mathrm{~h}$. Fractions were collected and assayed for immunoreactive GH. A pool of serum samples from 10 normal subjects was mixed and used as control. 


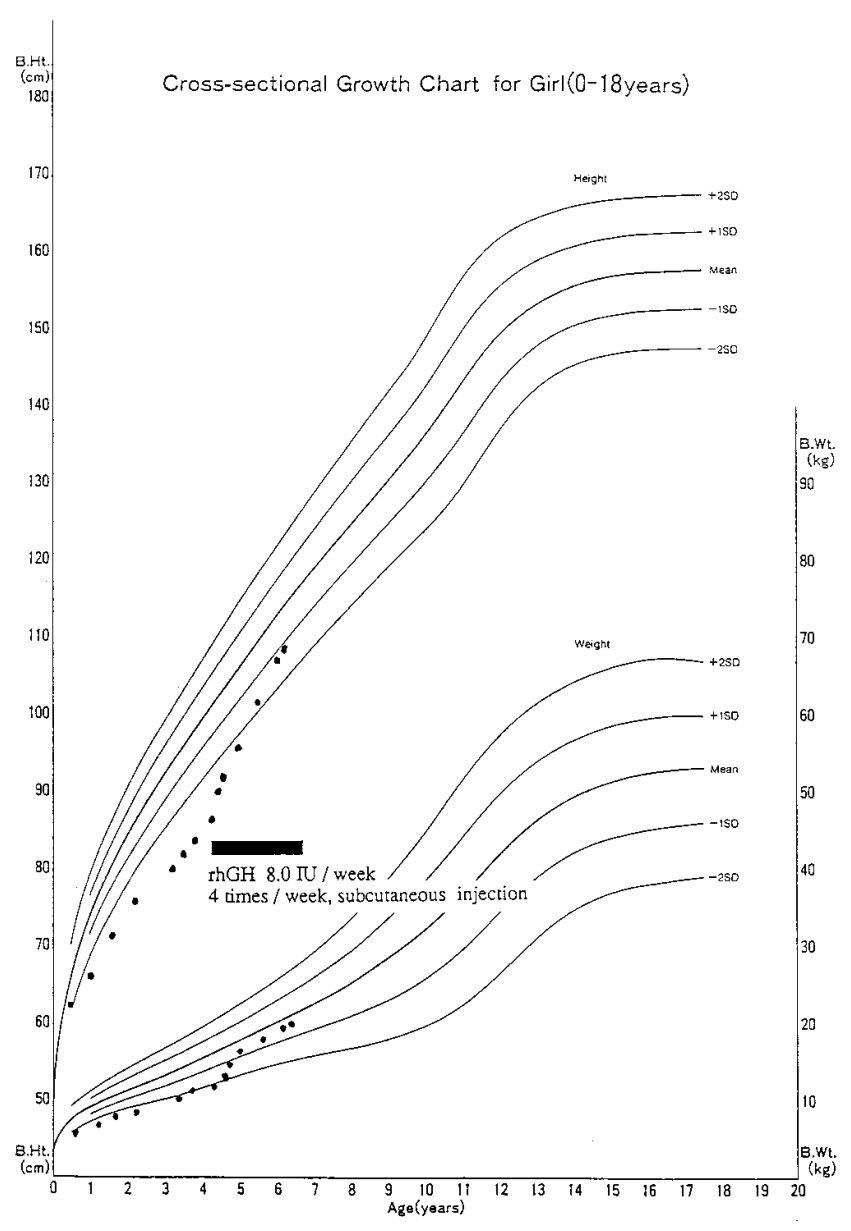

Figure 1. Growth chart for the patient. Her linear growth was markedly improved by treatment with rhGH.

Genetic analysis. Genomic DNA was isolated from peripheral blood leukocytes as described previously (12). DNA was amplified by PCR and analyzed as described previously (Fig. 2 A) (9). After identification of a mutation, direct sequencing was performed using a dsDNA cycle sequencing kit (Gibco Laboratories, Grand Island, NY) to exclude the possibility of misincorporation in PCR.

cDNA construction and expression of wild-type and mutant GH. GH cDNA was prepared as described previously (9). Mutant GH cDNA was constructed by site-directed mutagenesis, and its accuracy was confirmed by sequencing. Wild-type and mutant GH cDNA were subcloned into the NcoI-BamHI site in pET-32a (Novagen, Inc., Madison, WI), and transformed into Escherichia coli A494(D3). Wildtype and mutant $\mathrm{GH}$ were expressed as fusion proteins with the $E$. coli thioridoxin gene trxA, extracted by sucrose treatment, and digested with enterokinase. These proteins were purified using antihGH antibody-immobilized column and reverse-phase HPLC, confirmed by SDS-PAGE, and assayed by ELISA using hGH-specific polyclonal antibody.

Characterization of the functional properties of mutant $G H$. Direct binding of wild-type and mutant GH to recombinant human GHBP (rhGHBP) was determined by immunoprecipitation. [ $\left.{ }^{125} \mathrm{I}\right] \mathrm{hGH}(0.6$ $\mu \mathrm{Ci} / \mathrm{ml})$, rhGHBP $(0.6 \mathrm{nM})$, and anti-GHR mouse mAb (mAb 263, Agen, Brisbane, Australia) were incubated with increasing concentrations of wild-type and mutant $\mathrm{GH}$ in total volumes of $500 \mu \mathrm{l}$ at $4^{\circ} \mathrm{C}$ for 16 h. $50 \mu \mathrm{l} 10 \%$ anti-mouse IgG (goat), $50 \mu \mathrm{l} 1 \%$ normal mouse serum, and $300 \mu 15 \%$ polyethylene glycol were then added. The reaction mixture was incubated for an additional $4 \mathrm{~h}$ at $4^{\circ} \mathrm{C}$, centrifuged, and the radioactivity of the pellets was counted with a $\gamma$-counter (Pharmacia Biotech Inc.).

Detection of the association of wild-type and mutant GH to rhGHBP was performed as described previously $(13,14) .5 .4 \mu \mathrm{M}$ of either wild-type or mutant $\mathrm{GH}$ and $1.8 \mu \mathrm{M}$ rhGHBP were mixed in $0.2 \mathrm{M}$ potassium phosphate $(\mathrm{pH} 6.8) / 0.05 \%$ Tween 20 and equilibrated for $15 \mathrm{~min}$ at $25^{\circ} \mathrm{C}$. The reaction mixtures were then analyzed by HPLC. 50- $\mu$ l samples were applied to TSKgel G2000SW (Tosoh Technosystem, Tokyo, Japan) and eluted with $0.2 \mathrm{M}$ potassium phosphate (pH 6.8) at $1.0 \mathrm{ml} / \mathrm{min}$. Peaks were monitored by a fluorescence detector (Pharmacia Biotech Inc.).

GH-dependent tyrosine phosphorylation of GHR, janus kinase 2 (JAK2), and signal transducers and activators of transcription 5 (STAT5) in IM-9 cells was detected by Western blotting as described previously, with modifications $(9,15,16)$. Specific antibodies for GHR (mAb 263), JAK2, and STAT5 (Santa Cruz Biotechnology Inc., Santa Cruz, CA) were used for immunoprecipitation and antiphosphotyrosine $\mathrm{mAb}(\mathrm{RC} 20 \mathrm{H}$; Transduction Laboratories, Lexington, KY) was used for immunoblotting. Antibody binding was detected using an enhanced chemiluminescence kit (Amersham Corp., Arlington Heights, IL). Time course experiments of the tyrosine phosphorylation of GHR, JAK2, and STAT5 after GH stimulation indicated that the appropriate reaction times for quantitative analysis were $5 \mathrm{~min}$ for GHR and $10 \mathrm{~min}$ for JAK2 and STAT5 (data not shown).

Bioactivity of wild-type and mutant $\mathrm{GH}$ was also measured as rapid metabolic responses using the Cytosensor Microphysiometer (Molecular Devices, Menlo Park, CA), which is based on a pH-sensitive silicon sensor, the light-addressable potentiometric sensor (17). The Cytosensor system monitors the rate at which cultured cells acidify their local environment. The acidification rate represents both a measure of the metabolism of cells through excretion of acidic metabolites such as lactic acid and $\mathrm{CO}_{2}$, and of the control of intracellular $\mathrm{pH}$ through the regulation of proton transport across the membrane (18). As energy metabolism and proton homeostasis are involved in many cellular biochemical processes initiated on receptor activation, this system has been used to study many differently coupled receptors, including other growth factors and cytokines (19-21). Thrombopoietin induces acidification of the medium of $\mathrm{Ba} / \mathrm{F} 3$ cells in which thrombopoietin receptors were transfected (Takahashi, K., S. Hiroyuki, and J. Koga, manuscript in preparation). To establish a GH-sensitive cell line, the cDNA of the chimera of the extracellular domain of hGHR (cDNA 44-829, HindIII-MluI site), and of the transmembrane and cytoplasmic domain of human thrombopoietin receptor (cDNA 1474-1908, MluI-XhoI site) were constructed in pCR3-Uni (Invitrogen Corp., NV Leek, Netherlands) and transfected in $\mathrm{Ba} / \mathrm{F} 3$ cells. Stable transfectant $(\mathrm{BaF} / \mathrm{GM}$ cells) was selected using G418. Ba/F3-GM cells proliferated and acidified the medium depending on the concentration of $\mathrm{hGH}$. BaF/GM cells were maintained in RPMI 1640 containing $10 \%$ FCS and $100 \mathrm{ng} / \mathrm{ml} \mathrm{hGH}$. The extracellular acidification rate of wild-type and mutant $\mathrm{GH}$ was determined as described previously (21, and our unpublished results). $24 \mathrm{~h}$ before the assay, the cells were fixed on soft agarose, and the medium was replaced with RPMI 1640 containing $10 \%$ horse serum. $4 \mathrm{ng} / \mathrm{ml}$ wildtype or mutant $\mathrm{GH}$ was added to the fluid, and the change of $\mathrm{pH}$ in the medium was monitored using the microphysiometer.

\section{Results}

Identification of the GH-1 gene mutation in the proband. On the basis of clinical findings for the proband, we suspected that her circulating GH might be biologically inactive. To clarify genetic pathogenesis of bioinactive $\mathrm{GH}$, the sequence of her $\mathrm{GH}-1$ gene was determined after PCR amplification of the genomic DNA isolated from peripheral leukocytes (Fig. $2 A$ ). A heterozygous single-base substitution was identified in the proband's GH-1 gene. The mutation was confirmed by PCR direct 
A

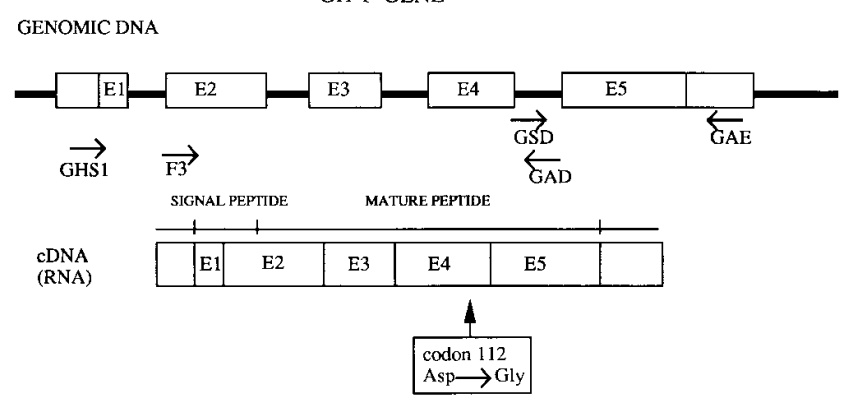

C
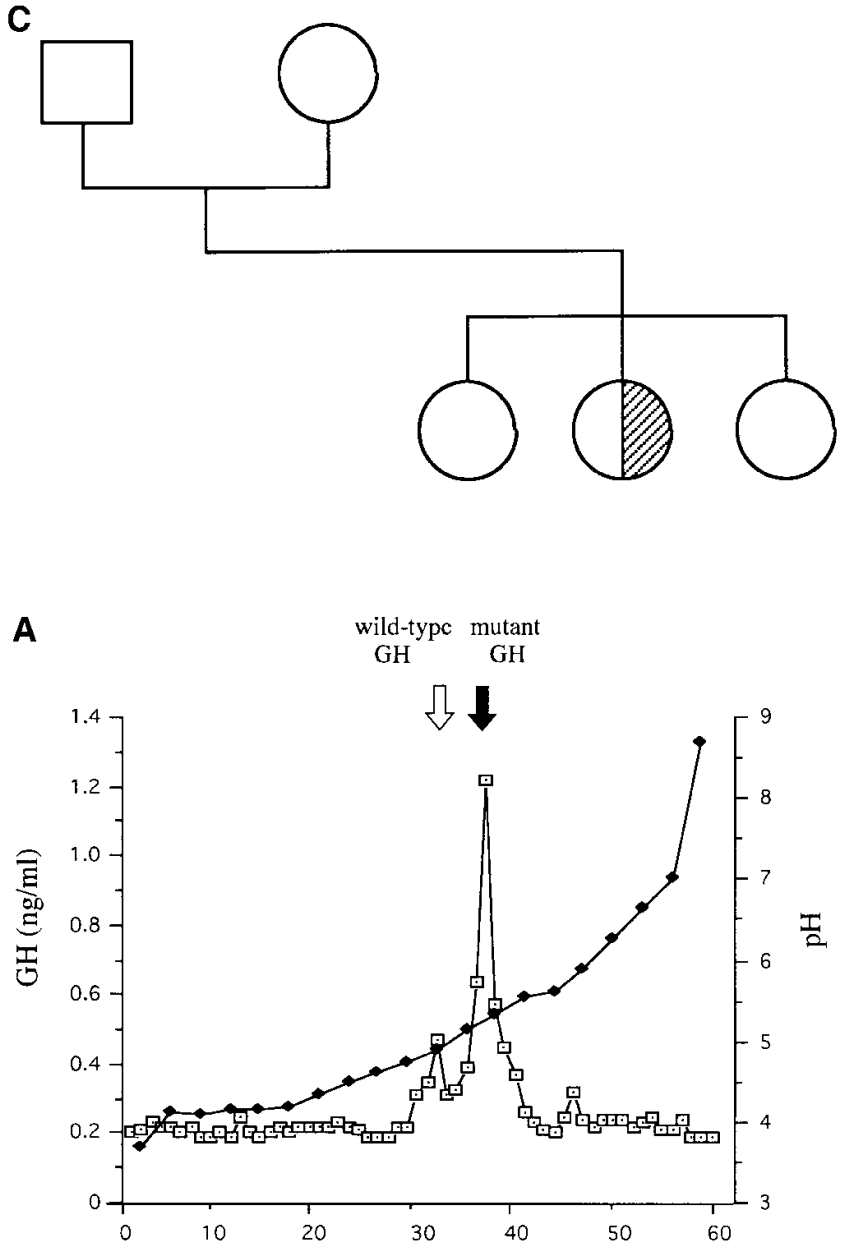

B

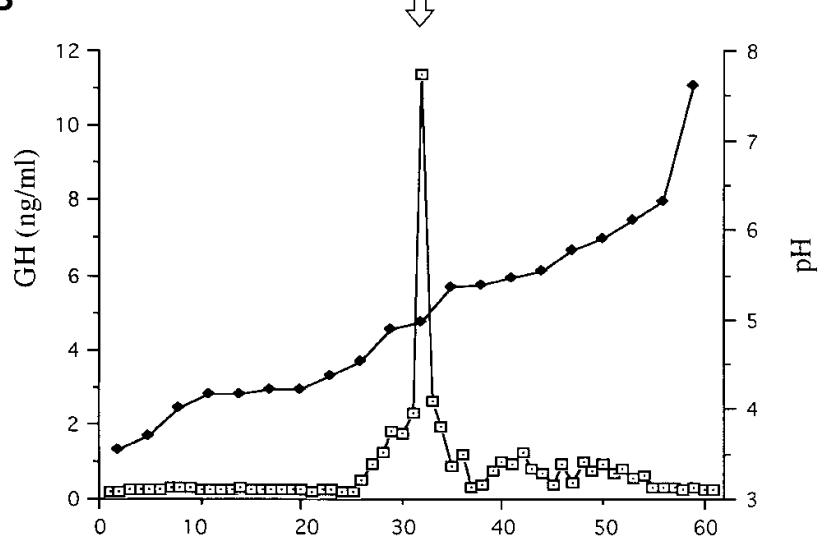

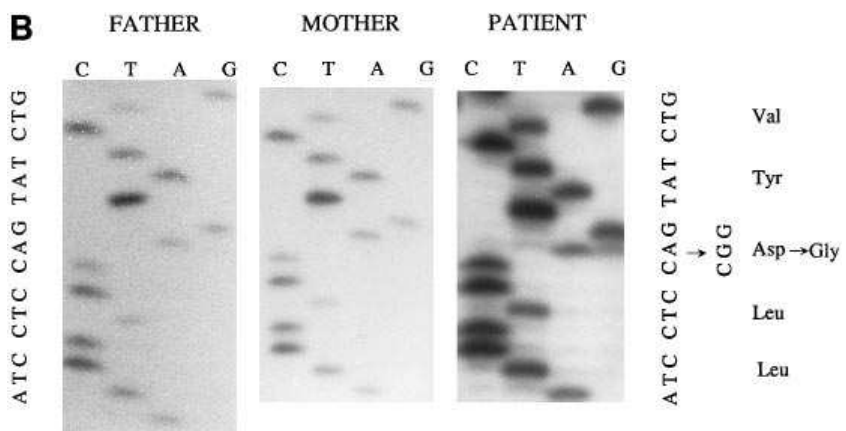

Figure 2. (A) GH-1 gene structure and primer design for PCR amplification. The five exons are indicated by boxes, and the locations of the PCR primers are indicated by arrows. The mutation at amino acid 112 (substitution of aspartic acid with glycine) is indicated. (B) Sequence of the mutated GH-1 gene. The heterozygous mutation of codon 112 from aspartic acid to glycine is indicated. $(C)$ Pedigree of family members and genotypes. Sequence analysis of the GH-1 gene was performed in all family members. A square denotes a male family member (father), circles denote female family members, and the half-solid circle denotes the patient with the heterozygote for GH-1 gene mutation.

sequencing analysis of genomic DNA (Fig. $2 B$ ). The substitution is predicted to convert codon 112 from aspartic acid to glycine. The mutation was considered to be sporadic in the family studies (Fig. $2 C$ ).

Detection of the mutant $G H$ molecule in the patient's serum. The missense mutation in the GH-1 gene was predicted to cause the change in the isoelectric point in the molecule. We confirmed the presence of the mutant GH in her serum using isoelectric focusing analysis. This study revealed that an abnormal GH peak ( $\mathrm{pH}$ 5.1) corresponding to the mutant $\mathrm{GH}$ was present predominantly in her serum (Fig. 3). Quantitative analysis revealed that the amount of mutant $\mathrm{GH}$ was 3.7-fold greater than wild-type $\mathrm{GH}$.

Failure of 1:2 GH-GHBP complex formation in the mutant $G H$. To assess whether this mutation of the GH-1 gene caused a reduction in bioactivity of $\mathrm{GH}$, we performed additional studies to define the functional properties of the substituted aspartic acid for glycine at amino acid 112. The wild-type and mutant GH cDNAs were inserted into an expression vector, and both proteins were expressed in E. coli and purified. First, binding capability to GHBP was compared in wild-type and mutant GH. $\left.{ }^{125} \mathrm{I}\right] \mathrm{GH}$ binding to rhGHBP was inhibited similarly by wild-type and mutant $\mathrm{GH}$ in a dose-dependent manner (data not shown). The $\mathrm{IC}_{50}($ mean $\pm \mathrm{SE})$ of the mutant $\mathrm{GH}$

Figure 3. Isoelectric focusing analysis of $\mathrm{GH}$ in serum from patient $(A)$ and control subjects $(B)$. Fractions were pooled separately and assayed for GH immunoreactivity (dotted open square). The $\mathrm{pH}$ gradient formed during isoelectric focusing is indicated by $\downarrow$. The isoelectric point of $\mathrm{GH}$ was $\mathrm{pH} 4.9$, and that of the D112G mutant was predicted to be $\mathrm{pH}$ 5.1. Wild-type and mutant $\mathrm{GH}$ peaks are shown as white and black arrows, respectively. 


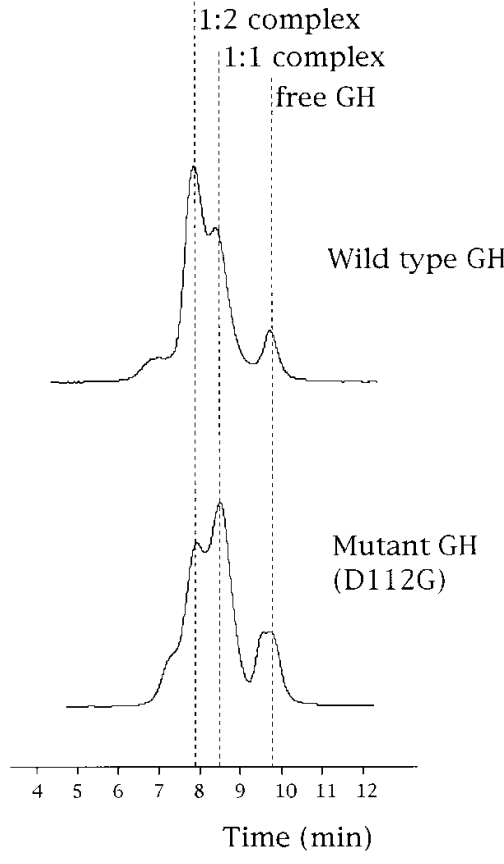

Figure 4. HPLC profile of free $\mathrm{GH}$ and $\mathrm{GH}-$ GHBP complex. Concentrations of wild-type and mutant GH were calibrated by HPLC, and $5.4 \mu \mathrm{M}$ of wild-type or mutant GH and 1.8 $\mu \mathrm{M}$ of rhGHBP were mixed and equilibrated for $15 \mathrm{~min}$ at $25^{\circ} \mathrm{C}$. Peaks indicated by dotted lines are, 1:2 GHGHBP complex, 1:1 GH-GHBP complex, and free form $\mathrm{GH}$, respectively.

$(1.2 \pm 0.4 \mathrm{nM}, n=3)$ to GHBP was not different from that of wild-type $\mathrm{GH}(1.4 \pm 0.3 \mathrm{nM}, n=3)$. hGH forms a 1:2 complex with the extracellular domain of its hGHBP (13). Second, the capability to dimerize the GHBP of mutant GH was determined. Sensitive solution assay based on gel filtration chromatography was used to distinguish 1:2 complex, 1:1 complex, and free-form $\mathrm{GH}(13,14)$. The elution profile from HPLC gel filtration revealed that mutant $\mathrm{GH}$ tended to form a 1:1 complex with GHBP, unlike wild-type GH (Fig. 4). Quantitative analysis revealed that the ratio of 1:2 complex to $1: 1$ complex was 1.24 for wild-type and 0.46 for mutant $\mathrm{GH}$, respectively.

Decreased tyrosine phosphorylation by mutant $G H$ of GHR, JAK2, and STAT5 in IM-9 cells. Subsequently, we analyzed the potency of wild-type and mutant $\mathrm{GH}$ to transduce the GH-dependent signal via GHR in the cells using Western blotting. Human myeloblast cell line IM-9 cells which express GHR show dose-dependent tyrosine phosphorylation of GHR (15). Mutant GH was less potent in stimulating tyrosine phosphorylation of GHR than wild-type GH in these cells (Fig. 5). Next, the potencies of wild-type and mutant GH to phosphorylate tyrosine residues in JAK2 and STAT5 were quantified. In tyrosine phosphorylation of JAK2, the potency of mutant $\mathrm{GH}$ was significantly reduced, to $26 \pm 7 \%$ compared to wild-type $\mathrm{GH}$ (Fig. 6, $A$ and $B$ ), and to $18 \pm 14 \%$ in STAT5 (Fig. 7, $A$ and $B$ ).

Less acidification activity of mutant $G H$ in metabolic responses. To determine bioactivity as metabolic responses of mutant $\mathrm{GH}$ in vitro, we used $\mathrm{BaF} / \mathrm{GM}$ cells in medium acidified by $\mathrm{hGH}$ in a dose-dependent manner using a microphysiometer. $\mathrm{BaF} / \mathrm{GM}$ cells stably express the chimera of the extracellular domain of hGHR and of the transmembrane and cytoplasmic domain of human thrombopoietin receptor, and sensitively respond to hGH. Since the bioassay system using $\mathrm{BaF} / \mathrm{GM}$ cells was artificially constructed, it remains to be elucidated whether the responsiveness of the cells to $\mathrm{GH}$ is physiological. Addition of wild-type GH resulted in a significant decrease in medium $\mathrm{pH}$, while mutant $\mathrm{GH}$ exhibited $38 \%$

(-) wild-type mutant $\mathrm{GH} \quad \mathrm{GH}$

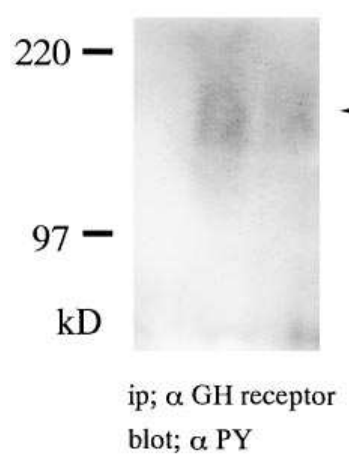

Figure 5. GH-dependent tyrosine phosphorylation of GHR in IM-9 cells. IM-9 cells were treated without $\mathrm{ml}$ wild-type or mutant $\mathrm{GH}$ for $5 \mathrm{~min}$ at $37^{\circ} \mathrm{C}$. Detergent lysates of these cells were immunoprecipitated by antiGHR antibody (mAb 263) and analyzed by Western blotting using an antiphosphotyrosine antibody $(\alpha \mathrm{PY})$ conjugated to horseradish $\mathrm{GH}(-)$, or with $100 \mathrm{ng} /$

peroxidase. Sizes are indicated to the left in kD. Arrow indicates $\mathrm{GH}$-stimulated tyrosine-phosphorylated $\mathrm{GH}$ receptor.

potency to acidify the medium compared to wild-type $\mathrm{GH}$ (Fig. 8).

\section{Discussion}

There have been several reports that bioinactive GH may be responsible for growth retardation (1-8). However, the molecular basis of bioinactive $\mathrm{GH}$ has not been elucidated. We have recently found the missense mutation $\mathrm{R} 77 \mathrm{C}$ in the $\mathrm{GH}-1$ gene of a 4.9-yr-old boy with severe short stature (-6.1 SD). The R77C mutant $\mathrm{GH}$ possessed a 6 times greater affinity to GHBP and inhibited the ability of 10 times more wild-type GH to stimulate tyrosine phosphorylation in IM-9 cells, therefore showing a dominant negative action (9). Because of the potent antagonistic action of R77C mutant GH, serum IGF-1 levels were unchanged by $3 \mathrm{~d}$ of daily subcutaneous injection of $0.1 \mathrm{U} \mathrm{hGH} / \mathrm{kg}$ body wt, and both serum IGF-1 levels and rate of linear growth appeared to increase transiently, but subsequently returned to values from before $\mathrm{GH}$ treatment despite continuation of $\mathrm{GH}$ therapy, indicating that $\mathrm{GH}$ treatment was ineffective in the patient with $\mathrm{R} 77 \mathrm{C}$ mutant $\mathrm{GH}$. We report here the first case of short stature in which characteristics were compatible with the criteria of bioinactive GH syndrome first suggested by Kowarski et al. (1). The proband was a 3-yr-old girl with short stature (3.6 SD below the mean for age and sex) and delayed bone age. She showed high basal serum GH levels and marked GH increases in response to provocative stimuli despite low IGF-1 levels. Her impaired somatic growth was significantly improved with exogenous $\mathrm{GH}$ treatment. These clinical findings suggest that her short stature may be caused by a biologically inactive $\mathrm{GH}$. Using isoelectric focusing analysis, we found the presence of abnormal $\mathrm{GH}$ molecules in her serum. Sequence analysis of GH-1 gene revealed a mutation: aspartic acid was substituted for glycine at codon 112 .

The crucial amino acid residues in the GH molecule for $\mathrm{GH}$ binding to its receptor were identified using homologueand alanine-scanning mutagenesis $(23,24)$. $\mathrm{GH}$ is one of the cytokine family and consists of four $\alpha$ helixes. Cunningham et al. $(13,23,24)$ found that $\mathrm{GH}$ contains two separate binding sites, 1 and 2, for GHR/GHBP binding. Site 1 is a larger binding site, and consists of weak determinants in helix 1 and stron- 


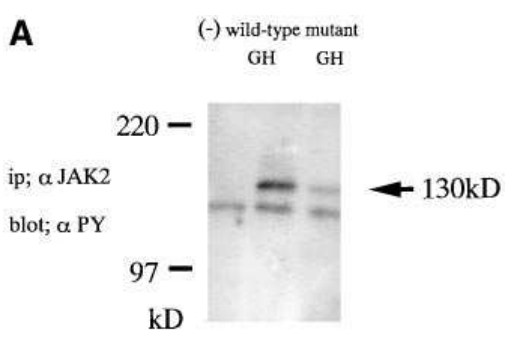

ip; $\alpha$ JAK2

blot; $\alpha$ JAK2
B

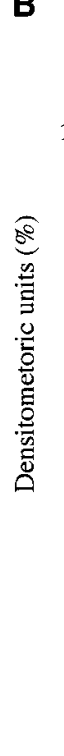

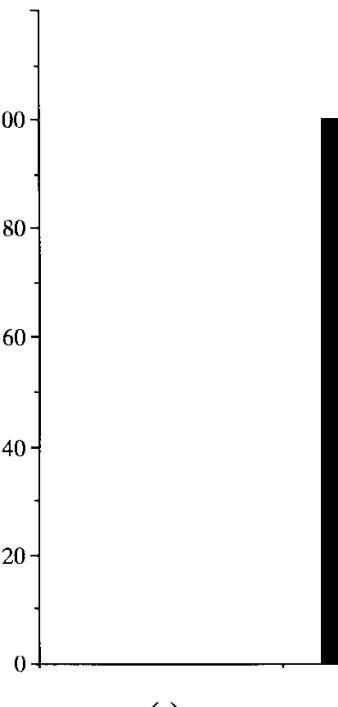

$(-)$

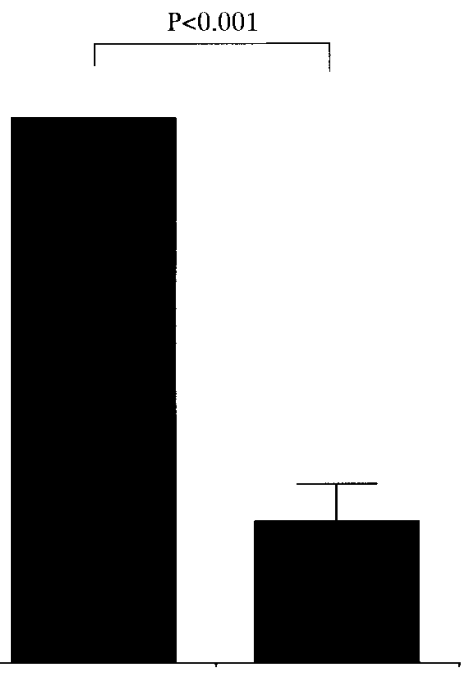

Wild-type GH
Figure 6. (A) GH-dependent tyrosine phosphorylation of JAK2 in IM-9 cells. IM-9 cells were treated without GH (-), or with $100 \mathrm{ng} / \mathrm{ml}$ wildtype or mutant $\mathrm{GH}$ for 10 min at $37^{\circ} \mathrm{C}$. Detergent lysates of these cells were immunoprecipitated by anti-JAK2 antibody and analyzed by Western blotting using an antiphosphotyrosine antibody. The membranes were stripped and reprobed with anti-JAK2 antibody (bottom). Sizes are indicated to the left in $\mathrm{kD}$. Arrow indicates GHstimulated tyrosine-phosphorylated JAK2, and arrowhead indicates JAK2.

$(B)$ Density of JAK2 bands was quantified with a densitometer, normalized by the quantity of JAK2, and compared in wild-type and mutant

$\mathrm{GH}$. Mean $\pm \mathrm{SE}$ values of three independent experiments were presented.

ger ones in the loop from residues 54 to 74 and in the central portion of helix 4. Site 2 determinants are located in the extreme amino terminus in the central portion of helix 3 . Codon 112 in which the mutation was found in our patient is located in the third $\alpha$ helix of the GH molecule within site 2 . It is generally accepted that GH binds two molecules of GHRGHBP simultaneously through sites 1 and 2 to form a $\mathrm{GH} \cdot(\mathrm{GHR}-\mathrm{GHBP})_{2}$ complex. Mutational analysis revealed that disruptive mutations in site 1 could not form 1:1 complexes of GH and GHBP, whereas mutations in site 2 could, suggesting that the complex forms sequentially-that is, $\mathrm{GH}$ binds one molecule of GHBP in site 1 , then binds a second GHBP in site 2. Therefore, it is plausible to speculate that the mutation in codon 112 of the GH-1 gene may not affect the binding of GHBP in site 1. Supporting this assumption, inhibition by mutant and wild-type $\mathrm{GH}$ of $\left[{ }^{125} \mathrm{I}\right] \mathrm{GH}$ binding to rhGHBP was nearly identical in our study. Sensitive solution assay based on gel filtration chromatography of the complex revealed that mutant $\mathrm{GH}$ tended to form a 1:1 complex with GHBP, unlike wild-type GH. These results indicated that mutant GH could bind to GHBP but was less potent in forming a 1:2 complex with GHR-GHBP by which the GH signal was transduced in the cells. Crystal structure analysis revealed that D112 was within the contact area touching the second hGHR (24). D112 is located in the third $\alpha$ helix of the GH molecule, and substituted glycine is not supposed to be favored in the he-
A

\section{B}

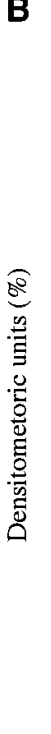

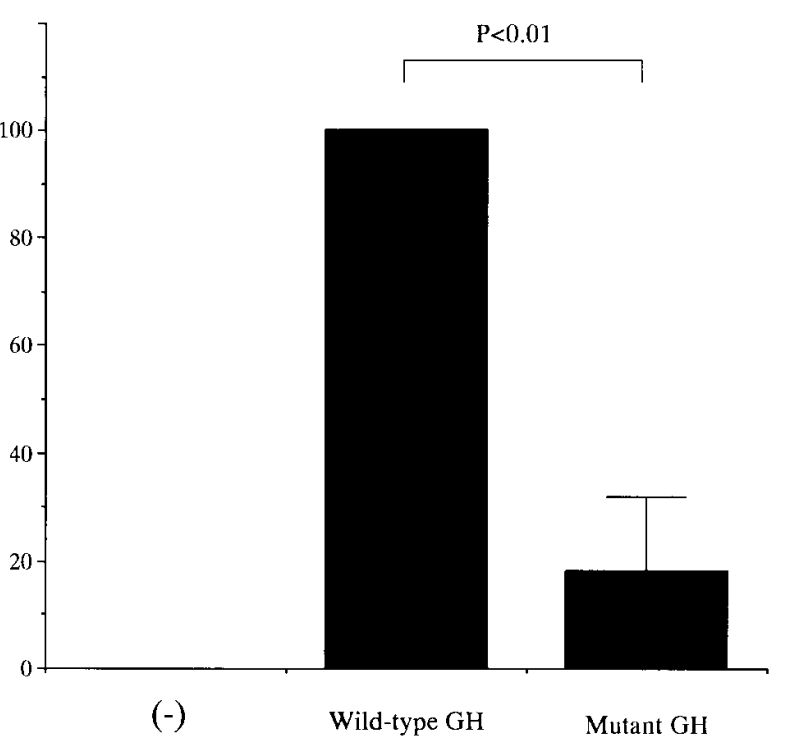

Figure 7. (A) GH-dependent tyrosine phosphorylation of STAT5 in IM-9 cells. IM-9 cells were treated as described in Fig. 6. Membranes were stripped and reprobed with anti-STAT5 antibody (bottom). Sizes are indicated to the left in $\mathrm{kD}$. Arrow indicates GHstimulated tyrosine-phosphorylated STAT5 and arrowhead indicates STAT5. (B) Density of STAT5 bands was quantified with a densitometer, normalized by the quantity of STAT5, and compared in wild-type and mutant GH. Mean \pm SE values of three independent experiments were presented. 


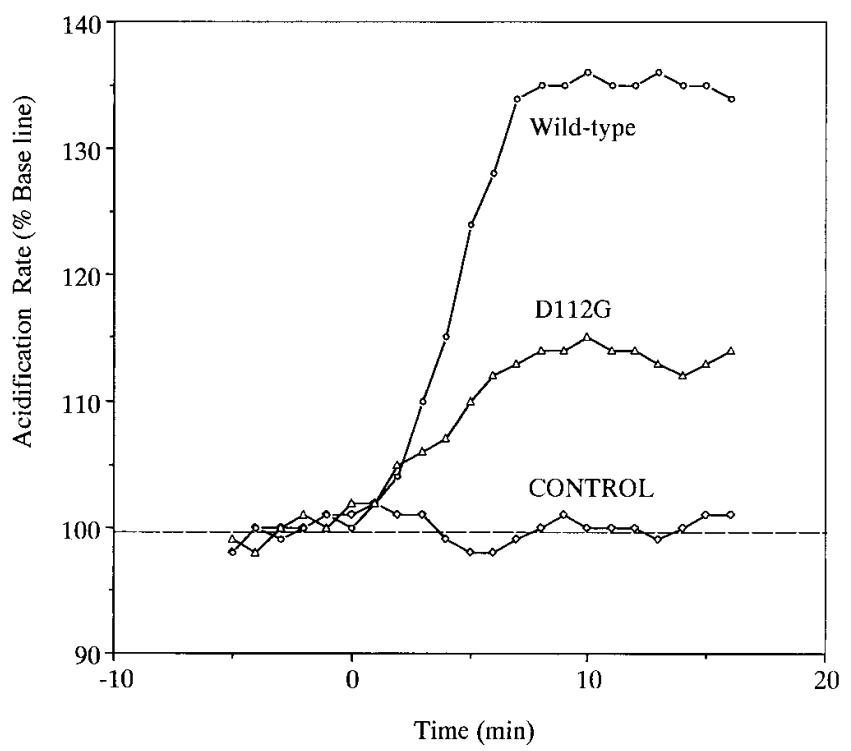

Figure 8. The acidification rate of the medium caused by wild-type and mutant $\mathrm{GH}$ in $\mathrm{BaF} / \mathrm{GM}$ cells was monitored using the Cytosensor. $Y$ axis indicates relative change of $\mathrm{pH}$ on the surface of the cells. $\mathrm{BaF} / \mathrm{GM}$ cells were treated with buffer only (control), or $4 \mathrm{ng} / \mathrm{ml}$ wild-type or mutant GH.

lix conformation. Therefore, the mutation could disrupt the third $\alpha$ helix and change the conformational structure of site 2 . Cunningham et al. (13) analyzed the $\mathrm{EC}_{50}$ values for GHBP dimerization by various mutant $\mathrm{GH}$ produced by alanine-scanning mutagenesis using the fluorescence homoquenching method. In their report, $\mathrm{D} 112 \mathrm{~A}$ showed $\mathrm{EC}_{50}$ values similar to those for wild-type $\mathrm{GH}$, suggesting that aspartic acid at codon 112 was not so important for site 2 . Taken together with our data, it is possible that the substituted amino acid glycine influenced the function of site 2 .

Dimerization of the GHRs induced by GH binding and subsequent sequential phosphorylation of protein tyrosine residues are crucially important for the signal transduction of $\mathrm{GH}$. Mutant $\mathrm{GH}$ was significantly less potent than wild-type $\mathrm{GH}$ in stimulating tyrosine phosphorylation of GHR, JAK2, and STAT5 in IM-9 cells. Sensitive bioassay for hGH as acidification rate responses using $\mathrm{BaF} / \mathrm{GM}$ cells revealed that D112G was less potent than wild-type $\mathrm{GH}$ in acidifying the medium in physiological concentrations. These data indicated that $\mathrm{D} 112 \mathrm{G}$ was less bioactive in exerting metabolic responses than wild-type GH.

It is of interest that mutant G120R, which is artificially introduced in site 2, prevented binding of the second GHBP (25). This analog was inactive as an agonist but acted as an antagonist to hGHR in IM-9 cells (15). Also, a G119R variant of bovine $\mathrm{GH}$ antagonized the action of $\mathrm{GH}$ when overexpressed in transgenic animals (26). Taken together with our data, the mutation around the site 2 epitope of the GH molecule seems to disrupt the dimerization of GHRs, thereby inhibiting the signal transduction of $\mathrm{GH}$.

Isoelectric focusing analysis of the proband's serum revealed that mutant $\mathrm{GH}$ was predominantly present, unlike wild-type $\mathrm{GH}$, despite the heterozygous mutation. That finding provides a plausible explanation for why this child suffered from short stature, but the mechanism by which the mutant $\mathrm{GH}$ level exceeded that of wild-type GH remains unknown.

In conclusion, we found a heterozygous missense mutation D112G in the GH molecule of a child with growth retardation. This mutant GH was bioinactive, since receptor dimerization and post-receptor signal transduction were significantly impaired compared to wild-type GH.

\section{Acknowledgments}

We thank Genentech, Inc. for supplying rhGHBP, Dr. Masaru Honjo of Mitsui Toatsu Chemicals, Inc. for excellent technical suggestions, Miss Chika Ogata and Miss Eriko Ohno for technical assistance, and Dr. Toru Yasunaga for performing GHBP assay.

This study was supported in part by a grant-in-aid for scientific research (c) 05807089, 06807082, 07671138 from the Japanese Ministry of Education, Science, Sports and Culture, and by grants from the Japanese Ministry of Health and Welfare, Novo Nordisk Growth, and the Growth Science Foundation in 1995 and 1996.

\section{References}

1. Kowarski, A.A., J. Schneider, E. Ben-Galim, V.V. Weldon, and W.H. Daughaday. 1978. Growth failure with normal serum RIA-GH and low somatomedin activity: somatomedin restoration and growth acceleration after exogenous GH. J. Clin. Endocrinol. Metab. 47:461-464.

2. Ilondo, M.M., M. Vanderschueren-Lodeweyckx, P. De Meyts, and E. Eggermont. 1990. Serum growth hormone levels measured by radioimmunoassay and radioreceptor assay: a useful diagnostic tool in children with growth disorders? J. Clin. Endocrinol. Metab. 70:1445-1451.

3. Hayek, A., and G.H. Peake. 1978. A new syndrome of short stature due to biologically inactive but immunoreactive growth hormone. Pediatr. Res. 12: 413. (Abstr.)

4. Rudman, D., M.H. Kutner, R.D. Blackston, R.A. Cushman, R.P. Bain, and J.H. Patterson. 1981. Children with normal-variant short stature: treatment with human growth hormone for six months. N. Engl. J. Med. 305:123-131.

5. Frazer, T.E., J.R. Gavin, W.H. Daughaday, R.E. Hillman, and V.V. Weldon. 1982. Growth hormone dependent growth failure. J. Pediatr. 101:12-15.

6. Plotnick, L.P., Q.L. Van Meter, and A.A. Kowarski. 1983. Human growth hormone treatment of children with growth failure and normal growth hormone levels by immunoassay: lack of correlation with somatomedin generation. Pediatrics. 71:324-327.

7. Bright, G.M., A.D. Rogol, A.J. Johanson, and R.M. Blizzard. 1983. Short stature associated with normal growth hormone and decreased somatomedin-C concentrations: response to exogenous growth hormone. Pediatrics. 71:576-580.

8. Valenta, L.J., M.B. Sigel, M.A. Lesniak, A.N. Elias, U.J. Lewis, H.G. Friesen, and A.K. Kershnar. 1985. Pituitary dwarfism in a patient with circulating abnormal growth hormone polymers. N. Engl. J. Med. 312:214-217.

9. Takahashi, Y., H. Kaji, Y. Okimura, K. Goji, H. Abe, and K. Chihara 1996. Short stature caused by a mutant growth hormone. N. Engl. J. Med. 334: 432-436.

10. Carlsson, L.M.S., S. Rosberg, R.V. Vitangcol, W.L.T. Wong, and K. Albertsson-Wikland. 1993. Analysis of 24-hour plasma profiles of growth hormone $(\mathrm{GH})$-binding protein, $\mathrm{GH} / \mathrm{GH}$-binding protein-complex, and $\mathrm{GH}$ in healthy children. J. Clin. Endocrinol. Metab. 77:356-361.

11. Tsvetnitsky, V., L. Auchi, A. Nicolaou, and W.A. Gibbons. 1995. Characterization of phospholipid methylation in rat brain myelin. Biochem. J. 307: 239-244.

12. Gross-Bellard, M., P. Oudet, and P. Champon. 1973. Isolation of highmolecular-weight DNA from mammalian cells. Eur. J. Biochem. 36:32-38.

13. Cunningham, B.C., M. Ultsch, A.M. De Vos, M.G. Mulkerrin, K.R. Clauser, and J.A. Wells. 1991. Dimerization of the extracellular domain of the human growth hormone receptor by a single hormone molecule. Science (Wash. DC). 254:821-825.

14. Duquesnoy, P., M. Sobrier, B. Duriez, F. Dastot, C.B. Buchanan, O. Savage, M.A. Preeve, C.T. Craescu, Y. Blouquit, M. Goosenes, and S. Amselem. 1994. A single amino acid substitution in the exoplasmic domain of the growth hormone $(\mathrm{GH})$ confers familial $\mathrm{GH}$ resistance (Laron syndrome) with positive GH-binding activity by abolishing receptor homodimerization. EMBO (Eur. Mol. Biol. Organ.) J. 13:1386-1395.

15. Silva, C.M., M.J. Weber, and M.O. Thorner. 1993. Stimulation of tyrosine phosphorylation in human cells by activation of the growth hormone receptor. Endocrinology. 132:101-108.

16. Smit, L.S., D.J. Meyer, N. Billestrup, G. Norstedt, J. Schwartz, and C. Carter-Su. 1996. The role of the growth hormone (GH) receptor and JAK1 and JAK2 kinases in the activation of Stats 1, 3, and 5 by GH. Mol. Endocrinol. 10: 
$519-533$

17. Hafeman, D.G., J.D. Parce, and H.M. McConnell. 1988. Light addressable potentiometric sensor for biochemical systems. Science (Wash. DC). 240: $1182-1185$

18. McConnell, H.M., J.C. Owicki, J.W. Parce, D.L. Miller, G.T. Baxter, H.G. Wada, and S. Pitchford. 1992. Microphysiometer: biological applications of silicon technology. Science (Wash. DC). 257:1906-1912.

19. Johnson, R.M., P.A. McNeeley, K. DeMoor, G.R. Stewart, B.S. Glaeser, and S. Pitchford. 1994. Recombinant human ciliary neurotrophic factor stimulates the metabolic activity of SH-SY5Y cells as measured by a cytosensor microphysiometer. Brain Res. 646:327-331.

20. Owicki, J.C., J.W. Parce, K.M. Kersco, G.M. Sigal, V.C. Muir, J.C. Venter, C.M. Fraser, and H.M. McConnell. 1990. Continuous monitoring of receptor-mediated changes in metabolic rates of living cells. Proc. Natl. Acad. Sci. USA. 87:4007-4011.

21. Pithford, S., K. De Moor, and B.S. Glaeser. 1995. Nerve growth factor stimulates rapid metabolic responses in PC12 cells. Am. J. Physiol. 268:C936C943.

22. Wells, J.A. 1991. Systematic mutational analysis of protein-protein interfaces. Methods Enzymol. 202:391-411.

23. Cunningham, B.C., and J.A. Wells. 1989. High-resolution epitope mapping of hGH-receptor interactions by alanine-scanning mutagenesis. Science (Wash. DC). 244:1081-1085.

24. De Vos, A.M., M. Ultsch, and A. Kossiakoff. 1992. Human growth hormone and extracellular domain of its receptor: crystal structure of the complex. Science (Wash. DC). 255:306-312.

25. Fur, G., B.C. Cunningham, R. Fukunaga, S. Nagata, D.V. Goeddel, and J.A. Wells. 1992. Rational design of potent antagonists to the human growth hormone receptor. Science (Wash. DC). 256:1677-1680.

26. Chen, W.Y., D.C. Wright, T.E. Wagner, and J.J. Kopchick. 1990. Expression of a mutated bovine growth hormone gene suppresses growth of transgenic mice. Proc. Natl. Acad. Sci. USA. 87:5061-5065. 